\title{
PENGARUH KOMPENSASI DAN PENGALAMAN KERJA TERHADAP KINERJA KARYAWAN PADA PT. INDO BALI NEGARA
}

\author{
Eka Bayu Purnawati ${ }^{1}$, Komang Krisna Heryanda ${ }^{2}$, \\ Putu Indah Rahmawati ${ }^{3}$
1,2,3 Jurusan Manajemen, Universitas Pendidikan Ganesha, Singaraja e-mail: ekabayu09@gmail.com¹, krisna.heryanda@undiksha.ac.id² indah.rahma@undiksha.ac.id ${ }^{3}$

\begin{abstract}
ABSTRAK
Penelitian ini bertujuan untuk mengkaji pengaruh sebagai berikut, (1) kompensasi dan pengalaman kerja terhadap kinerja, (2) kompensasi terhadap kinerja, (3) pengalaman kerja terhadap kinerja. populasi yang dalam penelitian ini adalah seluruh karyawan yang bekerja pada PT Indo Bali Negara yang berjumlah 39 orang karyawan. Berdasarkan karakteristik masalah yang diteliti maka penelitian ini menggunakan desain penelitian kuntitatif kausal. Teknik pengumpulan data pada penelitian ini yaitu pencatatan dokumen dan kuesioner. Teknik analisis data yang digunakan adalah teknik analisis regresi linier berganda. Hasil penelitian menunjukan bahwa kompensasi dan pengalaman kerja berpengaruh terhadap kinerja, kompensasi berpengaruh terhadap pengalaman kerja, kompensasi berpengaruh terhadap kinerja, dan pengalaman kerja berpengaruh terhadap kinerja.
\end{abstract}

Kata kunci: kinerja, kompensasi, pengalaman kerja

\begin{abstract}
The study aims to examine the following influences, (1) Compensation and work experience on performance, (2) Compensation for performance, (3) work experience on performance. The population in this study is all employees who work on PT Indo Bali Negara amounting to 39 employees. Based on the characteristics of the problems studied, this study used the design of causal cuntitular research. The data collection techniques in this research are document recording and questionnaire. The data analysis technique used is a double linear regression analysis technique. The results showed that compensation and work experience have an effect on performance, impactful compensation for work experience, impactful compensation performance, and work experience impacting performance.
\end{abstract}

Keywords:compensation, performance, work experience. 
Jurnal Prospek, Vol. 1 No. 2, Bulan Desember Tahun 2019

P-ISSN: 2685-5526

\section{PENDAHULUAN}

Perusahaan organisasi yang baik adalah organisasi yang mampu berusaha meningkatkan kemampuan sumber daya manusianya, karena sumber daya manusia hal yang paling penting dalam meningkatkan kinerja karyawan. Salah satu yang harus diperhatikan dalam pelaksanaan kegiatan dalam perusahaan yaitu tercapainya kinerja yang baik dan sesuai dengan standar kinerja yang ditetapkan perusahaan. Perusahaan yang berhasil dalam mencapai tujuannya atau tercapainya standar kinerja seringkali datang dari prilaku karawan itu sendiri. Hal ini sependapat dengan Mangkunegara (2013) mendefinisikan kinerja sebagai hasil kerja secara kualitas dan kuantitas yang di capai oleh seorang pegawai dalam melaksanakan tugas nya sesuai dengan tanggung jawab yang diberikan kepadanya.

Perusahaan PT. Indo Bali Negara merupakan perusahaan yang bergerak dalam bidang uaha pembuatan tepung ikan dan ikan sarden dalam kaleng. Kinerja karyawan yang sangat penting bagi perusahaan sebagai alat pengukur keberhasilan dalam menjalankan usaha. Jika semakin tinggi kinerja karyawan, maka keuntungan perusahaan juga semakin tinggi. PT. Indo Bali Negara menetapkan standar kerja karyawan yang di sesuaikan dengan bagian/unit kerjanya.

Data menunjukan bahwa kinerja yang dicapai bagian produksi masih lebih rendah dari standar kinerja yang di harapkan, sehingga kinerja karyawan PT. Indo Bali Negara berkategori rendah. Tentunya permasalahan ini harus diperhatikan oleh pihak manajemen untuk tetap menjaga kelangsungan hidup perusahaan kedepannya melalui peningkatan kinerja karyawan. Peningkatan kinerja harus dilakukan karena adanya kesenjangan antara prestasi kerja yang diharapkan dengan kenyataan yang sebenarnya terjadi. Menurut Samsudin (2006: 187) Kompensasi adalah segala sesuatu yang diterima para karyawan sebagai balas jasa atas kerja mereka, dan kompensasi itu sendiri dapat dibagi menjadi dua yaitu kompensasi langsung dan tak langsung. Menurut Ruky(2001: 10) Kompensasi langsung merupakan imbalan jasa kepada pegawai yang diterima secara langsung, rutin atau periodic karena yang bersangkutan telah memberikan bantuan atau sumbangan untuk mencapai tujuan organisasi, dan kompensasi langsung meliputi gaji, bonus atau insentif, komisi. Selain kompensasi langsung, kompensasi tak langsung juga mempunyai peran yang tak kalah pentingnya untuk meningkatkan kinerja karyawan. Perusahaan tidak dibenarkan memberikan upah yang tidak sesuai dengan pedoman yang ditetapkan oleh pemerintah yaitu harus sesuai dengan persyaratan yang tercantum dalam Upah Minimum Regional (UMR). Penggajian harus memperhatikan peraturan pemerintah, seperti ketentuan tentang UMR. Jika upah yang diterima karyawan lebih rendah dari UMR, maka karyawan kurang maksimal dalam memberdayakan diri untuk bekerja.

Selain kompensasi, untuk meningkatkan kinerja karyawan juga tidak terlepas dengan pengalaman kerja yang dimiliki oleh karyawan perusahaan tersebut. Robbins dan Timothy (2008:162) menyatakan bahwa: "Pengalaman kerja adalah tingkat penguasan pengetahuan dan keterampilan seseorang dalam bekerja yang tampaknya menjadi sebuah dasar pemikiran yang baik atas kinerja pegawai". Pengalaman juga memberikan damppak pada setiap keputusan yang diambil merupakan keputusan yang tepat. Hal tersebut mengindikasikan bahwa semakin lama masa kerja yang dimiliki karyawan maka karyawan akan semakin baik pula kualitas kinerja yang dihasikan.

Penelitian Oktavia (2006) tentang pengalaman kerja memberikan hasil bahwa tidak terdapat pengaruh pengalaman kerja terhadap pengambilan keputusan karyawan. Orang yang berpengalaman merupakan calon karyawan yang siap pakai. Semakin luaspengalaman kerja seseorang, semakin terampil melakukan pekerjaan dan semakin sempurna pola pikir dan sikap 
untuk mencapai tujuan yang telah ditetapkan. Hal ini juga di dukung dari hasil penelitian yang dilakukan oleh Napitupulu dan Nasution (2016) menyatakan bahwa terdapat pengaruh yang positif dan signifikan antara pengalaman kerja terhadap kinerja karyawan. Sedangkan hasi penelitian dari Agustina dan Anggita (2017) menyatakan bahwa pengalaman kerja berpengaruh positif terhadap kinerja.

Berdasarkan latar belakang masalah diatas terdapat beberapa permasalahan yang dapat diidentifikasi sebagai berikut: (1) Masih buruknya aspek kesehatan di Indonesia yang membuat tidak meratanya pelayanan kesehatan yang berkualitas bagi seluruh rakyat Indonesia. (2) Masyarakat masih merasakan sejumlah kendala ketika mengakses layanan kesehatan tersebut, terutama terkait dengan ketentuan yang diterapkan Pemerintah. (3) Layanan BPJS kesehatan hanya dapat melindungi diri di wilayah Indonesia saja, berbeda dengan layanan kesehatan swasta lainnya yang bisa memproteksi kesehatan masyarakatnya hingga di seluruh dunia. (4) Tidak adanya kesempatan untuk mendapat fasilitas kelas 1. Meskipun masyarakat telah mendaftar pada kelas 1 dan kelas 2, namun kenyataannya memang terjadi hal yang tidak sesuai. Masyarakat pengguna BPJS sering mendapat fasilitas kelas 3.

Bedasarkan kajian teoritis dan empiris tersebut, peneliti tertarik untuk melakukan penelitian di perusahaan ini karena teori-teori menunjukan bahwa kinerja pegawai di pengaruhi oleh kompensasi dan pengalaman kerja, artinya ketika ada permasalahan kinerja dalam perusahaan ini maka ada kemungkinan besar dipengaruhi oleh kompensasi yang kurang dan pengalaman kerja yang kurang pula namun untuk mengetahui penyebabkan pasti dari masalah tersebut maka harus dilakukan penelitian. Latar belakang tersebut dapat diketahui bahwa ketidak konsistenan pengaruh kompensasi dan pengalaman kerja terhadap kinerja karyawan serta terdapat permasalahan terkait kinerja karyawan yang terjadi di PT. Indo Bali Negara sehingga menyebabkan peneliti tertarik untuk melakukan penelitian dengan judul "Pengaruh Kompensasi dan Pengalaman Kerja Terhadap Kinerja Karyawan Pada PT. Indo Bali Negara".

Salah satu cara manajemen untuk meningkatkan prestasi kerja, memotivasi dan meningkatkan kepuasan dan kinerja karyawan adalah melalui kompensasi (Mathis dan Jackson, 2000). Menurut Panggabean (2005:181), kompensasi dapat didefinisikan sebagai setiap bentuk penghargaan yang diberikan kepada karyawan sebagai balas jasa atas konstribusi yang mereka berikan terhadap organisasi. Selain itu Saydam (2008:181) mengemukakan bahwa kompensasi adalah sebagai bentuk balas jasa perusahaan terhadap pengorbanan waktu, tenaga, dan pikiran yang telah diberikan mereka (karyawan) kepada perusahaan. Mondy dan Noe (2008:374) membagi kompensasi menjadi dua bagian yaitu kompensasi keuangan langsung terdiri atas gaji, upah dan insentif (komisi dan bonus).

Secara sederhana kompensasi merupakan suatu yang diterima karyawan untuk balas jasa kerja mereka. Untuk menciptakan efisien, sistem kompensasi juga harus sejalan dengan konteks organisasi. Hal ini dimaksudkan bahwa sistem pembayaran dan pemberian kompensasi harus sesuai dengan peraturan dan penetapan dari perusahaan dengan sistem penilaian kerja karyawan untuk menciptakan keadilan dalam pemberian kompensasi pada seluruh karyawannya. Untuk kinerja optimal, sistem kompensasi harus terdiri dari kebijakan yang konsisten baik antara karyawan individu atau sendiri dan dengan kebijakan lainnya.

Karyawan harus konsisten dengan strategi pengembangan organisasi (misalnya, organisasi kerja, kualitas total) dan dengan orang-orang perusahaan (bisnis strategi). Meskipun minat dalam berbagai perspektif telah tumbuh secara signifikan dalam banyak disiplin ilmu manajemen. Oleh karena itu, penggunaan program atau insentif dalam upaya meningkatkan kinerja membutuhkan kaitan yang jelas dan terlihat antara kinerja dan kompensasi serta iklim kepercayaan antara orang-orang yang bekerja dan orang-orang yang memberikan imbalan.

Agar karyawan termotivasi untuk meningkatkan kinerjanya, sebaiknya perusahaan menggunakan ketrampilan sebagai dasar perhitungan kompensasi. Kepada karyawan juga perlu dijelaskan bahwa kompensasi yang diberikan, di hitung berdasarkan ketrampilan dan 
kemampuan mereka dalam mengembangkan ketrampilannya untuk menunjang penyelesaian tugas yang diberikan kepadanya (Denis Chenevert, Michel Tremblay 2011).

$\mathrm{H1}$ : Ada pengaruh kompensasi terhadap kinerja karyawan di PT. Indo Bali Negara Kecamatan Negara.

Pengalaman kerja merupakan salah satu hal yang mendasari karyawan dalam melaksanakan tugasnya. Seorang karyawan yang memiliki pengalaman kerja lebih banyak tentu akan lebih mengerti apa yang harus dilakukan ketika menghadapi sebuah kesulitan. Dengan pengalaman karyawan memiliki kualitas sumber daya manusia yang tinggi dalam meningkatkan kemampuan kerjanya, baik dalam kecepatan kerja maupun dalam mutu hasilnya. Menurut Nitisemito (2002) pengalaman kerja adalah suatu atau kemampuan yang dimiliki oleh para karyawan dalam menjalankan tugas-tugas yang dibebankan kepadanya.

Menrut Sutrisno (2009: 158), pengalaman kerja adalah suatu dasar/acuan seorang karyawan dapat menempatkan diri secara tepat kondisi, berani mengambil resiko, mampu menghadapi tantangan dengan penuh tanggung jawab serta mampu berkomunikasi dengan baik terhadap berbagai pihak untuk tetap menjaga produktivitas, kinerja dan menghasilkan individu yang kompeten dalam bidangnya.

$\mathrm{H}$ 2: Ada pengaruh pengalaman kerja terhadap kinerja karyawan di PT. Indo Bali Negara Kecamatan Negara.

Saydam (2008: 181) mengemukakan bahwa kompensasi adalah sebagai bentuk balas jasa perusahaan terhadap pengorbanan waktu, tenaga, dan pikiran yang telah diberikan mereka(karyawan) kepada perusahaan. Perusahaan tidak dibenarkan memberikan upah yang tidak sesuai dengan pedoman yang ditetapkan oleh pemerintah yaitu harus sesuai dengan persyaratan yang tercantum dalam Upah Minimum Regional (UMR). Penggajian harus memperhatikan peraturan pemerintah, seperti ketentuan tentang UMR. Jika upah yang diterima karyawan lebih rendah dari UMR, maka karyawan kurang maksimal dalam memberdayakan diri untuk bekerja.

Selain kompensasi, untuk meningkatkan kinerja karyawan juga tidak terlepas dengan pengalaman kerja yang dimiliki oleh karyawan perusahaan tersebut. Robbins dan Timothy (2008:162) menyatakan bahwa: "Pengalaman kerja adalah tingkat penguasan pengetahuan dan keterampilan seseorang dalam bekerja yang tampaknya menjadi sebuah dasar pemikiran yang baik atas kinerja pegawai". Pengalaman juga memberikan damppak pada setiap keputusan yang diambil merupakan keputusan yang tepat. Hal tersebut mengindikasikan bahwa semakin lama masa kerja yang dimiliki karyawan maka karyawan akan semakin baik pula kualitas kinerja yang dihasikan.

H3: Ada pengaruh kompensasi dan pengalaman kerja terhadap kinerja karyawan di PT. Indo

Bali Negara Kecamatan Negara.

\section{METODE}

Penelitian ini dilakukan untuk mengetahui pengaruh kompensasi dan pengalaman kerja terhadap kinerja pegawai di PT. Indo Bali Negara. Dalam penelitian ini terdiri dari dua variabel bebas, yaitu kompensasi $\left(X_{1}\right)$ dan pengalaman kerja $\left(X_{2}\right)$, serta kinerja sebagai variabel terikat (Y).

Berdasarkan karakteristik masalah yang diteliti maka penelitian ini mengguanakan penelitian desain penelitian kuantitatif kausal. Desain penelitian kausal berguna untuk mengukur hubungan variaberl-variabel yang dapat mempengaruhi variabel lainnya (Sugiyono, 2014:56). Desain penelitian asosiatif.yang bersifat kausal memiliki beberapa tahapan terdiri dari (1) merumuskan masalah, (2) mengkaji teori, (3) merumuskan hipotesis, (4) mengumpulkan data, (5) mengolah data, (6) menarik kesimpulan.

Subjek dalam penelitian ini adalah karyawan PT. Indo Bali Negara, sedangkan objek dalam penelitian ini adalah kompensasi dan pengalaman kerja, dan kinerja karyawan. Populasi 
yang digunakan dalam penelitian ini adalah PT. Indo Bali Negara bidang poduksi, dengan jumlah seluruh karyawan di bidang produksi yaitu 39 orang.

Jenis data yang dibutuhkan dalam penelitian ini dapat digolongkan menjadi dua yaitu data primer dan sekunder.Data primer adalah data yang meliputi kompensasi finansial, disiplin kerja dan produktivitas kerja. Data kompensasi finansial, disiplin kerja dan produktivitas kerja dapat dilihat pada rekapan catatan perusahaan sedangkan untuk non finansial diperoleh dari hasil wawancara karyawan dan dipertegas oleh pemilik perusahaan.

Data sekunder adalah data yang diperoleh dari sumber kedua yaitu, pemilik dari PT Indo Bali Negara. Data yang dikumpulkan sebagai data sekunder adalah jumlah karyawan dan data absensi.

Metode yang digunakan untuk mengumpulkan data dalam penelitian ini yaitu dengan menggunakan kuesioner. Menurut (Sugiyono, 2010:199) kuesioner merupakan cara pengukuran dengan menghadapkan seorang respoden dengan sebuah pernyataan dan kemudian diminta jawaban dari lima pilihan jawaban, dimana nilai jawaban memiliki nilai jawaban yang berbeda. Dalam penelitian ini digunakan skala likert. Dengan menggunakan skala ini, peneliti dapat mengukur sikap, pendapat, dan persepsi responden. Sebelum digunakan untuk pengumpulan data dilapangan, kuesioner terlebih dahulu diuji reliabilitas dan validitasnya.

\section{HASIL DAN PEMBAHASAN}

HASIL

Model analisis linier berganda digunakan untuk mengetahui pengaruh kompensasi dan pengalaman kerja terhadap kinerja karyawan PT. Indo Bali Negara secara simultan maupun parsial. Penelitian ini mengunakan model analisis regresi linier berganda dengan bantuan program aplikasi komputer (SPSS) 22.0 for Windows.

Tabel 1

Hasil Analisis Regresi Berganda

\begin{tabular}{cccc}
\hline Parameter & Koefisien & P-value & Alpha \\
\hline $\mathrm{Ryx}_{1, \mathrm{x}_{2}}$ & 0,840 & 0,000 & 0,005 \\
\hline $\mathrm{R}^{2} \mathrm{yx}_{1, \mathrm{X}_{2}}$ & 0,705 & - & - \\
\hline $\mathrm{Pyx}_{1}$ & 0,656 & 0,000 & 0,005 \\
\hline $\mathrm{P}^{2} \mathrm{yx}_{1}$ & 0,430 & - & - \\
\hline $\mathrm{Pyx}_{2}$ & 0,592 & 0,000 & 0,005 \\
\hline $\mathrm{P}^{2} \mathrm{yx}_{2}$ & 0,350 & - & - \\
\hline$\varepsilon$ & 0,295 & - & - \\
\hline
\end{tabular}

Hipotesis yang pertama yaitu untuk Hipotesis yang pertama yaitu untuk menguji pengaruh parsial dari kompensasi terhadap kinerja. Bedasarkan uji regresi liner berganda yang telah dilakukan, diperoleh hasil dimana variabel kompensasi memiliki nilai $t_{\text {hitung }}$ sebesar 5,218 dengan nilai sig. t 0,000lebih kecil dari alpha yaitu 0,05 yang berarti $\mathrm{H}_{0}$ ditolak. Hasil ini menunjukan bahwa ada pengaruh signifikan secara parsial dari kompensasi terhadap kinerja.

Selanjutnya yaitu hipotesis kedua yaitu untuk menguji pengaruh parsial dari pengalaman kerja terhadap kinerja. Bedasarkan uji regresi liner berganda yang telah dilakukan, diperoleh hasil yang menunjukan variabel pengalaman kerja memiliki nilai $t_{\text {hitung }}$ sebesar 4,404 dengan 
nilai sig. $\mathrm{t}$ 0,000lebih kecil dari alpha yaitu 0,05 yang berarti $\mathrm{H}_{0}$ ditolak. Hasil ini menunjukan bahwa ada pengaruh signifikan secara parsial dari pengalaman kerja terhadap kinerja.

Hipotesis penelitian yang terakhir bertujuan untuk menguji pengaruh simultan dari kompensasi dan pengalaman kerja terhadap kinerja. Bedasarkan uji regresi liner berganda yang telah dilakukan, diperoleh hasil dimana nilai $F_{\text {hitung }}$ sebesar 43,066 dengan nilai sig. $F$ 0,000lebih kecil dari alpha yaitu 0,05 yang berarti $\mathrm{H}_{0}$ ditolak. Hasil ini menunjukan bahwa ada pengaruh signifikan secara simultan dari kompensasi dan pengalaman kerja terhadap kinerja. Besar sumbangan pengaruh kompensasi dan pengalaman kerja terhadap kinerja yaitu sebesar $70,5 \%$.

Berdasarkan hasil perhitungan yang telah dilakukan menggunakan SPSS versi 22 untuk menguji koefisien determinasi dari data kuesioner yang telah diolah yang ditunjukan oleh Lampiran 07 adalah menunjukan nilai Adjusted $R$ Squere $\left(R^{2}\right)$ adalah 0,705 nilai tersebut cukup 1 (satu) yang berarti variabel kompensasi dan pengalaman kerja memberikan hanya sebagian informasi yang dibutuhkan untuk memprediksi variabel keputusan pembelian atau dapat diartikan bahwa kompensasi dan pengalaman kerja memberikan pengaruh sebesar $70,5 \%$ terhadap kinerja, sementra sisanya $29,5 \%$ dipengaruhi oleh variabel lain di luar model..

Struktur hubungan kausal kompensasi $\left(\mathrm{x}_{1}\right)$ dan pengalaman kerja $\left(\mathrm{x}_{2}\right)$ terhadap kinerja $(\mathrm{y})$ seperti nampak pada gambar 1

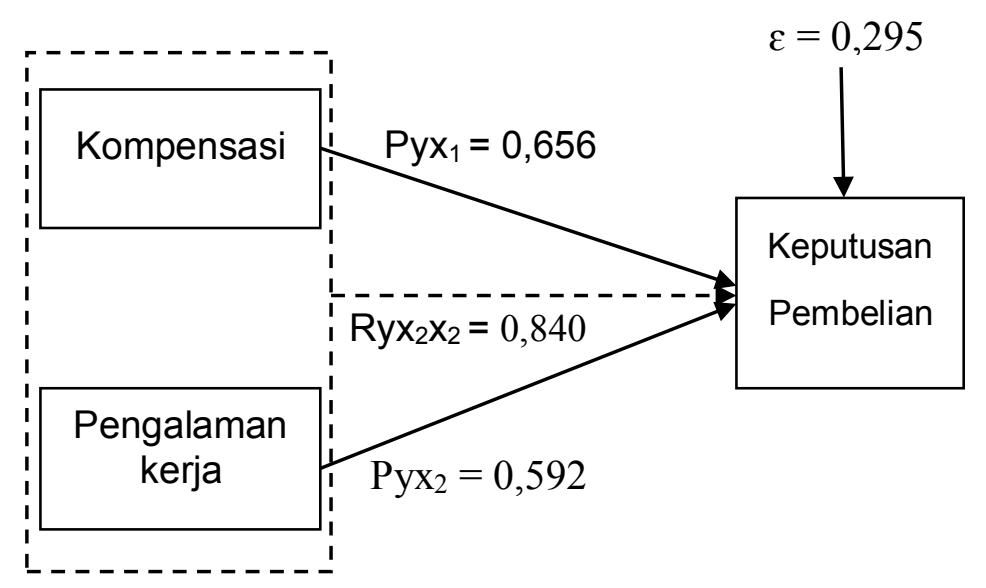

Gambar 1 Struktur Hubungan $\mathrm{x}_{1}$, dan $\mathrm{x}_{2}$ terhadap $\mathrm{y}$

Konstanta sebesar 0,314 berarti bahwa apabila variabel kompensasi, variabel pengalaman kerja dan variabel lain yang memengaruhi nilainya sama dengan nol, maka kinerja karyawan PT. Indo Bali Negara sebesar 0,134.

Koefisien kompensasi yaitu sebesar 1,421 berarti bahwa apabila variabel kompensasi meningkat sebesar satu satuan, maka kinerja akan mengalami kenaikan menjadi 1,735 dengan asumsi bahwa variabel lainya adalah tetap.

Koefisien pengalaman kerja yaitu sebesar 0,512 berarti bahwa apabila variabel pengalaman kerja meningkat sebesar satu satuan, maka kinerja akan mengalami kenaikan menjadi 0,826 dengan asumsi bahwa variabel lainya adalah tetap.

\section{PEMBAHASAN}

Dari hasil analisis yang telah dilakukan dapat dibuktikan bahwa kompensasi berpengaruh postif dan signifikan terhadap kinerja karyawan PT. Indo Bali Negara. Melihat hasil tersebut maka dapat disimpulkan bahwa ketika kompensasi yang diberikan itu sesuai atau melebihi dengan harpan karyawan maka akan meningkatkan kinerja para karyawan. Hasil ini sejalan dengan teori yang dikemukakn oleh Mathis dan Jackson (2000), yang menyatkan bahwa salah 
satucara manajemen untuk meningkatkan prestasi kerja, memotivasi dan meningkatkan kepuasan dan kinerja karyawan adalah melalui kompensasi.

Dalam pemahamanya, ketika karyawan diberikan kompensasi yang bersifat finasnsial maka kinerja karyawan tersbut akan meningkat atau menurun tergantung pada nominal yang diberikan oleh perushaan. Perushaan harus memperhitungkan secara tepat antara kemampuan dan kebuthan karyawanya. Apabila salah dalam memperhitungkan hal tersbut maka akan ada ketimpangan di salah satu pihak, dan akan berakibat fatal bagi perusahaan dan juga karyawan. Contoh ketimpangan yang terjadi adalah ketika perushaan memberikan terlalu banyak kompensasi untuk menyenagkan pegawainya, maka perushaan tersebut akan terbebani secara finansial karena biaya kompensasi yang terbilang tinggi. Sedangkan bila kompenasi terlalu rendah maka karaywan akan merasa tidak dihargai dan tentunya menurunkan kinerja mereka. Oleh karena itu manajemen harus mampu memutuskan biaya yang dikeluarkan untuk kompensasi.

Hasil dari uji regresi linier berganda yang mengujikan secara parsial variabel pengalaman kerja terhadap kinerja menunjukan bahwa variabel pengalaman kerja berpengaruh secara positif dan signifikan. Hal ini berarti pengalaman kerja dari seorang karyawan akan menunjakan bagaimana kinerjanya dalam mengerjakan tugas-tugas yang diberikan. Semakin banyak pengalaman yang dimiliki karyawan tersebut tertuama pada bidang kerjanya, maka akan semakin baik pula kinerjanya. Sebaliknya semakin minim pengalaman maka kinerjanya akan semakin kurang baik. Hal ini sejalan dengan teori yang dikemukakan oleh Sutrisno (2009: 158), pengalaman kerja adalah suatu dasar/acuan seorang karyawan dapat menempatkan diri secara tepat kondisi, berani mengambil resiko, mampu menghadapi tantangan dengan penuh tanggung jawab serta mampu berkomunikasi dengan baik terhadap berbagai pihak untuk tetap menjaga produktivitas, kinerja dan menghasilkan individu yang kompeten dalam bidangnya.

Dengan hasil tersebut maka dapat dipahami bahwa ketika pengalaman karaywan banyak maka kinerjanya juga meningkat. Hal ini disebabkan oleh pengalaman yang akan bersifat pembelajaran, sehingga setiap tindakan yang berulang-ulang terutama dibidang yang sama seperti pengepakan dalam bidang produksi, akan memberikan efek belajar bagi karyawan sehingga dengan belajar setiap hari karayawan tersebut akan memiliki tingkat kecepatan, kemampuan, dan refleks yang akan meningkat juga seiring waktu dalam bidang yang karyawan tersebut geluti. Dengan demikian akan sangat penting bagi karyawan mempunyai banyak pengalaman di bidang yang mereka tekuni, agar kinerja yang mereka hasilkan juga akan lebih baik daripada karaywan yang minim pengalaman.

Bedasarkan hasil perhitungan yang telah dilakukan, menunjukan bahwa ada secara bersama-sama variabel kompensasi dan pengalaman kerja berpengaruh signifikan terhadap karyawan PT. Indo Bali Negara dengan sumbangan pengaruh sebesar $70,3 \%$ sedangkan sisanya $29,3 \%$ dipengaruhi oleh variabel lain di luar model. Hasil ini sejalan dengan teori Saydam (2008: 181) dan juga teoriRobbins dan Timothy (2008:162).

Dengan hasil ini artinya ketika perusahaan ingin meningkatkan kinerja dari karyawankaryawan mereka dengan cara memperbaiki kompensasi dan lebih selektif dalam memilih karayawan menurut peneliti kebijakan tersebut sudah tepat, bila melihat dari hasil penelitian. Hasil ini menjadikan temuan bagi manajemen perushaan, dimana temuan tersebut mengandung masalah yang harus segera diselaikan oleh manajemen perushaan. Masalah tersebut tentu berkaitan dengan kompensasi yang diberikan dan juga pengalaman karaywan di PT. Indo Bali Negara kurang memadai atau masih minim, sehingga ketika manajemen meningkat kedua variabel ini maka perushaan akan mendapatkan hasil dimana kinerja para karaywanya akan meningkat dan produktivitas akan lebih baik lagi.

\section{SIMPULAN DAN SARAN Simpulan}


Jurnal Prospek, Vol. 1 No. 2, Bulan Desember Tahun 2019 P-ISSN: 2685-5526

Berdasarkan hasil analisis dan pembahasan yang telah dibahas pada bab sebelumnya, maka dapat ditarik beberapa kesimpulan yaitu, (1) kompensasi berpengaruh positif dan signifikan terhadap kinerja karyawan di PT. Indo Bali Negara. (2) Pengalaman kerja secara parsial berpengaruh positif dan signifikan terhadap kinerja karyawan di PT. Indo Bali Negara. (3) Kompensasi dan pengalaman kerja secara bersama-sama berpengaruh positif dan signifikan terhadap kinerja karyawan di PT. Indo Bali Negara.

\section{Saran}

Bedasarkan hasil analisis pembahasan dan beberapa kesimpulan pada penelitian ini, adapun saran-saran yang dapat diberikan melalui hasil penelitian ini agar mendapat hasil yang lebih baik yaitu sebagai berikut:

Untuk penelitian selanjutnya dalam bidang manajemen pemasaran khususnya tentang kinerja pada suatu perushaan, diharapkan melibatkan variabel-variabel lain yang mempengaruhi kinerja. Ataupun memperbanyak variabel yang digunakan dalam penelitian selanjutnya, agar teori-teori yang dikemukan lebih handal digunakan oleh perushaan.

Diharapkan penelitian ini dapat menjadi refrensi atau pertimbangan bagi manajamen SDM atau HRD PT. Indo Bali Negara. Dengan hasil penlitian kemudian menjadi solusiyang dihasilkan oleh peneliti, tentu akan menjadi nilai tambah lagi bila dinukan oleh perushaan sebagai refrensi dalam pengambilan keputusanselnjutnya.

\section{DAFTAR PUSTAKA}

Agustina, Duwi dan Wenni Anggita. 2017. Effect of Independence, Professional Expertise, Work Experience and Performance of Supervisors on the Performance of Savings and Loans Cooperatives in the Province of Bangka Belitung Island Proceeding of Community Development.

Alwi, Syafaruddin. 2001. Manajemen Sumber Daya Manusia, Strategi Keunggulan Kompetitif, Yogyakarta:: BPFE

Arikunto. 2006. Prosedur Penelitian Suatu Pendekatan Praktek. Jakarta: PT. Rineka Cipta

Bili, Wanceleslaus dkk. 2018. "Pengaruh Pengalaman Kerja terhadap Kinerja Pegawai di Kantor Kecamatan Laham Kabupaten Mahakam Ulu”. E-Journal Pemerintahan Integratif

Budi, Sasongko. Basuki dan Hendaryatno.2004. Jurnal. Auditor dan Dilema Etika. SNA VII

Danang, Sunyoto. 2009. Analisis Regresi dan Uji Hipotesis. Yogyakarta: Media Pressindo

Fauzi, Usman. 2014. "Pengaruh Kompensasi terhadap Kinerja Kayawan pada PT. Trakindo Utama Samarinda". Jurnal IImu Administrasi Bisnis

Hariandja, Marihot Tua Efendi. 2002. Manajemen Sumber Daya Manusia, Jakarta: Cetakan Pertama, Grasindo.

Hasibuan, M. 2002. Organisasi dan Motivasi: Dasar Peningkatan Produktivitas. Jakarta: Bumi Aksara.

Ghozali, Imam. 2009. Aplikasi Analisis Multivariate dengan Program SPSS Semarang: UNDIP.

Foster, Bill dan Karen R. Seeker. 2001. Pembinaan Untuk Meningkatkan Kinerja Karyawan. Jakarta: PT. Toko Gunung Agung Tbk.

Mahmudi. 2007. Manajemen Kinerja Sektor Publik. Yogyakarta: BPFE

Mangkunegara, A. Prabu. 2000. Evaluasi Kinerja SDM. Bandung: Refika Aditama. 
Jurnal Prospek, Vol. 1 No. 2, Bulan Desember Tahun 2019

P-ISSN: 2685-5526

Mathis, Robert L. dan John H. Jackson. 2000. Manajemen Sumber Daya Manusia. Buku Kedua, Edisi Pertama. Jakarta: Salemba Empat.

Martoyo, Susilo. 2007. Manajemen Sumber Daya Manusia, Edisi 5, Cetakan Pertama. Yogyakarta: BPFE

Miner, Jhon. 2007. Organization Behavior: Performence and Productivity, Firs Edition. New York: Random House

Mondy, R. Wayne dan Noe, R. M. 2008. Manajemen Sumber Daya Manusia. Jakarta: Erlangga

Nasution, S dan Napitupulu, R. M. 2016. Metode Research: Penelitian IImiah. Ed.1, Cet.8. Bumi Aksara. Jakarta.

Nawawi, H. Hadari. 2008. Manajemen Sumber Daya Manusia. Yogyakarta: Gadjah Mada University Press

Nitisemito, Alex S. 2002. Manajemen Personalia. Jakarta: Ghalia Indonesia.

Octavianus, W. Raymond dan Adolfina. 2018. "Pengaruh Pengalaman Kerja dan Pelatihan Kerja terhadap Kinerja Kayawan PT. Telkom Indonesia Cabang Manado". Jurnal EMBAVol.6 No.3

Panggabean, Murtiana S. 2002. Manajemen Sumber Daya Manusia, Cetakan Pertama. Jakarta: Ghalia Indonesia

Prawirosentono, Suyadi. 2008. Manajemen Sumber Daya Manusia Kebijakan Kinerja Karyawan. Yogyakarta: BPFE.

Rivai,Veithzal. 2004. Manajemen Sumber Daya Manusia Untuk Perusahaan. Edisi Pertama. Jakarta: PT Raja Grafindo Persada.

Robbins, Stephen P. dan Timothy A. Judge. 2008. Perilaku Organisasi. Jakarta: Salemba Empat

Samsudin, Sadili. 2006. Manajemen Sumber Daya Manusia, Cetakan ke-1. Bandung: Pustaka Setia 2006. Manajemen Sumber Daya Manusia. Bandung: Pustaka

Simamora, Henry. 2004. Manajemen Sumber Daya Manusia. ,Jakarta: STIE YKPN

Saydam, Ghozali. 2008. Manajemen Sumber Daya Manusia.. Jakarta: Binarupa,

Sugiyono. 2009. Metode Penelitian Administratif. Bandung: CV. Alfabeta. 2010. Statistika Untuk Penelitian. Bandung: CV. Alfabeta.

Sutrisno, Edi. 2009. Manajemen Sumber Daya Manusia EDisi Pertama. Jakarta: Media Group 2014. Metodologi Penelitian Pemdidikan. Bandung: CV. Alfabeta.

Suryabrata, Sumadi. 2000. Metode Penelitian. PT. Raja Grafindo Persada, Jakarta

Timothy A. Judge. 2008. Perilaku Organisasi Edisi Ke-12. Jakarta: Salemba Empat 